\title{
Analysis of cesarean section rate according to Robson's classification in an urban health centre in Senegal
}

\author{
Magatte Mbaye, Mamour Gueye*, Mame Diarra Ndiaye Gueye, \\ Ndeye Khady Sene Niang, Jean Charles Moreau
}

Gynaecologic and Obstetric Clinic, Aristide Le Dantec Teaching Hospital, PO BOX 3001, Pasteur Avenue, Cheikh Anta Diop University, Dakar, Senegal

Received: 31 May 2015

Accepted: 10 July 2015

\section{*Correspondence:}

Dr. Mamour Gueye,

E-mail: mamourmb@yahoo.fr

Copyright: (C) the author(s), publisher and licensee Medip Academy. This is an open-access article distributed under the terms of the Creative Commons Attribution Non-Commercial License, which permits unrestricted non-commercial use, distribution, and reproduction in any medium, provided the original work is properly cited.

\begin{abstract}
Background: Robson, proposed a new classification system, the Robson's Ten-Group Classification System to allow critical analysis according to characteristics of pregnancy. The objective was to describe caesarean rates in an urban health centre in Dakar using Robson's Ten groups classification

Methods: This study was performed in Philippe Senghor health centre in Dakar (Senegal), a secondary health centre that performs CS since 2011. Before this date, only midwifes performed deliveries in this centre. The study took place between 1 January and 31 December 2013. All patients who delivered during this period by CS were included.

Women were classified in 10 groups according to Robson's classification, using maternal characteristics and obstetrical history. For each group, we calculated its relative size and its contribution to the overall caesarean rate.

Results: The overall rate of caesarean was $18.2 \%$. The main contributors to the overall caesarean rate were primiparous women in spontaneous labour (group 1) and women with previous caesarean section (group 5). Further analysis of group 1 showed that more than half of CS indications in this group were fetal-pelvic disproportion in $55.2 \%$ and fetal hypoxia in $27 \%$.

Conclusion: The Robson's classification is easy to use. Each maternity unit can compare its rates with those of units with similar level, to find whether some groups of women have very high rates of caesarean sections. Attention should be made because CS rates is rising up and will be problematic in our low resource countries. It is time to implement obstetric audits to lower the CS rates.
\end{abstract}

Keywords: Caesarean section rate, Robson's Ten groups classification system

\section{INTRODUCTION}

Rates of caesarean section are rising worldwide. World Health Organization advises that Caesarean Section (CS) rates should not be more than $15 \%$, with some evidence that CS rates above $15 \%$ are not associated with additional reduction in maternal and neonatal mortality and morbidity. ${ }^{1}$ Analysing CS rates in different countries, including primary vs. repeat CS and potential reasons of these, provide important insights into the solution for reducing the overall CS rate. Robson, proposed a new classification system, the Robson's Ten-Group
Classification System to allow critical analysis according to characteristics of pregnancy.

In Dakar the capital of Senegal, Aristide Le Dantec teaching hospital is the national reference centre in Obstetrics and Gynaecology. More than 12000 deliveries per year were performed in this department. In 2005, this biggest maternity of the whole country was closed for rehabilitation because of its age. This lead to redeployment of doctors in secondary health centres in Dakar and suburbs. Philippe Senghor health centre was one on the secondary health centres concerned, where any caesarean section was performed before. An obstetric team started 
surgical procedures in this centre in 2011. After 2 years, we decided to evaluate. The aim of this study was to investigate CS rates at a secondary care centre in Dakar and make analysis based on the 10-group classification.

\section{METHODS}

This study was performed in Philippe Senghor health centre in Dakar (Senegal), a secondary health centre that performs CS since 2011. Before this date, only midwifes performed deliveries in this centre. The study took place between 1 January and $31^{\text {st }}$ December 2013 . All patients who delivered during this period by CS were included. Socio-demographic and obstetric relevant data were collected. Women were classified in 10 groups according to Robson's classification, using maternal characteristics and obstetrical history. For each group, we calculated its relative size and its contribution to the overall caesarean rate.

Furthermore, we analysed the indications of CS in the groups that made the greatest contribution to the global CS rate.

\section{RESULTS}

The total number of women delivered during the study period was 4176 , out of which CS deliveries were 760 leading to a rate of $18,2 \%$.

Analysis based on Robson's ten-group showed that Group 1 (nulliparous, single cephalic, >37 weeks in spontaneous labour) made the greatest contribution to the total $\mathrm{CS}$ rate. Group 5 (previous CS, single cephalic, >37 weeks) had the second highest contribution to the CS rate and then group 3 (multiparous (excluding previous CS), single cephalic, $>37$ weeks in spontaneous labour) placed third.

Furthermore, we analysed the Group $5(\mathrm{n}=157,20,5 \%)$. Only $31,2 \%$ had more than 1 previous caesarean section. Out of 157 CS procedures, elective CS were performed 37 times and emergency CS, 122 times. CS rates of each group are shown separately in Table 1.

In group 1 (nulliparous, single cephalic, $>37$ weeks in spontaneous labour), more than half of CS indications were fetal-pelvic disproportion (55.2\%) and fetal hypoxia in $27 \%$ in this group.

Table 1: Distribution of the rates of caesarean sections in the Robson 10 group classification.

\begin{tabular}{|llll|}
\hline No & Groups & $\begin{array}{l}\text { Relative } \\
\text { size of } \\
\text { group }\end{array}$ & $\begin{array}{l}\text { Percen } \\
\text { tages } \\
(\%)\end{array}$ \\
\hline $1 \quad \begin{array}{l}\text { Nulliparous, single cephalic, } \\
>37 \text { weeks in spontaneous } \\
\text { labour }\end{array}$ & $\begin{array}{l}(270 / 760) \\
\text { Nulliparous, single cephalic, } \\
>37 \text { weeks, induced or CS }\end{array}$ & 34,2 \\
\hline
\end{tabular}

\begin{tabular}{|llll|}
\hline \multicolumn{3}{|c|}{ before labour } & \\
\hline 3 & $\begin{array}{l}\text { Multiparous (excluding } \\
\text { previous CS), single cephalic, } \\
>37 \text { weeks in spontaneous } \\
\text { labour }\end{array}$ & 17,6 \\
\hline & $\begin{array}{l}\text { Multiparous (excluding } \\
\text { previous CS), single cephalic, } \\
>37 \text { weeks, induced or CS } \\
\text { before labour }\end{array}$ & (29/760) & 3,9 \\
\hline 5 & $\begin{array}{l}\text { Previous CS, single cephalic, } \\
>37 \text { weeks }\end{array}$ & $(159 / 760)$ & 20,5 \\
\hline 6 & All nulliparous breeches & $(40 / 760)$ & 6 \\
\hline 7 & $\begin{array}{l}\text { All multiparous breeches } \\
\text { (including previous CS) }\end{array}$ & $(27 / 760)$ & 4,5 \\
\hline 8 & $\begin{array}{l}\text { All multiple pregnancies } \\
\text { (including previous CS) }\end{array}$ & $(22 / 760)$ & 2,4 \\
\hline 9 & $\begin{array}{l}\text { All abnormal lies (including } \\
\text { previous CS) }\end{array}$ & $(15 / 760)$ & 2,6 \\
\hline 10 & $\begin{array}{l}\text { All single cephalic, <36 weeks } \\
\text { (including previous CS) }\end{array}$ & $(17 / 760)$ & 2,1 \\
\hline
\end{tabular}

Data expressed in absolute numbers (n) and percentage $(\%)$.

\section{DISCUSSION}

Most Caesarean sections are classified according to the reason for the surgery. ${ }^{2,3}$ It is then difficult to compare CS rates with others because the same terms are not usually used. In 2001 Dr Michael Robson, of the National Maternity Hospital, Dublin, proposed the new Ten Group Classification System (TGCS). These 10 groups are mutually exclusive, simple to use and read yet include the total sample. ${ }^{4}$

The TGCS is used worldwide and The WHO applied the Robson 10 group classifications to a multi-country dataset. ${ }^{1}$ The Robson 10 Group Classification System facilitates comparative analyses of Caesarean sections between hospitals/centres nationally, internationally and globally. ${ }^{4}$

In Senegal, the national CS rate is $4.4 \% .^{5}$ Nevertheless, we notice a wide discrepancy between hospitals CS rates and other centres. In some hospital in the capital, we usually go above $40 \%$.

Each group on the TGCS accounts for a particular type of population. The first group is traditionally a low risk population but in itself is a large proportion of pregnant women and therefore accounts for a sizable percentage of the section rate. This group made the greatest contribution to the total CS rate in our study. Caution should be made because this fact can lead to raise CS rate of group 5. During our dailies obstetrics audits, we highlighted this fact. Caesarean sections are more often made for fetal-pelvic disproportion reasons or fetal hypoxia. In our centre and most of other centres in Senegal, the means to detect fetal hypoxia are amniotic fluid aspect and fetal heart rate distress assessed clinically. This leads to over diagnose fetal hypoxia. 
Over the past couple of decades, CS rates have continued to rise worldwide. In some countries, such as Brazil, Mexico and Turkey, CS rates have exceeded $40 \%{ }^{6}$

Use of the Robson criteria allows standardised comparisons of data across countries and timepoints and identifies the subpopulations driving changes in caesarean section rates. ${ }^{7}$

As Vogel et al. noticed it in a WHO survey; women who have previously had a caesarean section are an increasingly important determinant of overall caesarean section rates in countries with a moderate or low Human Development Index. ${ }^{7}$ Seeing how CS are going on and reasons for CS in our study, we are expecting in a couple of years that Group 5 becomes first. Young medical doctors are frightened by vaginal delivery after caesarean section cause to pelvis is usually only clinically assessed and CT pelvimetry is rarely done for financial reasons. Strategies to reduce the frequency of the procedure should include avoidance of medically unnecessary primary caesarean section. Improved case selection for induction and prelabour caesarean section could also reduce caesarean section rates.

\section{CONCLUSION}

The Robson's classification is easy to use. Each maternity unit can compare its rates with those of units with similar level, to find whether some groups of women have very high rates of caesarean sections. Attention should be made because CS rate is rising up and will be problematic in our low resource countries. It is time to systematise obstetric audits to lower the CS rates.

We decide to implement this classification system in order to improve our practice and lower CS rates in our centre.

Funding: No funding sources Conflict of interest: None declared

Ethical approval: The study was approved by the Institutional Ethics Committee

\section{REFERENCES}

1. Betran AP, Gulmezoglu AM, Robson M, Merialdi M, Souza JP, Wojdyla D, et al. WHO global survey on maternal and perinatal health in Latin America: classifying caesarean sections. Reprod Health. 2009;6:18.

2. Thomas J. The National Sentinel Caesarean Section Audit Report. London. RCOG Press 2001.

3. Turcot L, Marcoux S, Fraser WD. Multivariate analysis of risk factors for operative delivery in Nulliparous women. Canadian early amniotomy study group. Am J Obst Gynae 1997; 176: 395-402.

4. Robson MS. Can we reduce the caesarean section rate? Best Pract Res Clin Obstet Gynaecol. 2001;15(1):179-94.

5. Agence Nationale de la Statistique et de la Démographie (ANSD) [Sénégal], et ICF International. 2015. Sénégal: Enquête Démographique et de Santé Continue (EDSContinue 2014). Rockville, Maryland, USA: ANSD et ICF International.

6. Chong C, Su LL, Biswas A. Changing trends of cesarean section births by the Robson Ten Group Classification in a tertiary teaching hospital. Acta Obstet Gynecol Scand. 2012;91(12):1422-7.

7. Vogel JP, Betran AP, Vindevoghel N, Souza JP, Torloni MR, Zhang J, et al. Use of the Robson classification to assess caesarean section trends in 21 countries: a secondary analysis of two WHO multicountry surveys. Lancet Glob Health. 2015;3(5):e260-70.

Cite this article as: Mbaye M, Gueye M, Gueye MDN, Niang NKS, Moreau JC. Analysis of cesarean section rate according to robson's classification in an urban health centre in senegal. Int J Reprod Contracept Obstet Gynecol 2015;4:1100-2. 